\title{
Cornu aspersum (Gastropoda: Helicidae) in Western Ukraine with an overview of introduced species of land molluscs from this area
}

\author{
Nina Gural-Sverlova \& Roman GuRAL \\ State Museum of Natural History, National Academy of Sciences of Ukraine, Teatralna 18, UA-79008 Lviv, Ukraine, \\ e-mail: sverlova@pip-mollusca.org (corresponding author), (D) https://orcid.org/0000-0002-3892-5338 \\ (D) https://orcid.org/0000-0002-1546-1956
}

\begin{abstract}
Gural-Sverlova N. \& Gural R., 2021: Cornu aspersum (Gastropoda: Helicidae) in Western Ukraine with an overview of introduced species of land molluscs from this area. - Malacologica Bohemoslovaca, 20: 123-135. https://doi.org/10.5817/MaB2021-20-123

Publication date: 9. 12. 2021.

The first findings of Cornu aspersum in the Lviv region are described, including the shell size and shell colouration variability. A review of the known records of $C$. aspersum in different regions of Ukraine, from the second half of the 19th century to the present day, is also presented. The most probable ways of penetration and the possibility of further acclimatization of this species in Western Ukraine are discussed. The chronology of the records of introduced species of land molluscs in Western Ukraine is described in tabular form, which, to a large extent, should reflect the chronology of their penetration into this area. It is noted that the majority of alien species began to be found in Western Ukraine only at the end of the 20th or the beginning of the 21st century. Simultaneously several species appeared here, previously known only for the south of the country.
\end{abstract}

Key words: terrestrial molluscs, brown garden snail, introduction, alien species, Western Ukraine

\section{Introduction}

Since the end of the 20th century, new alien species of land molluscs have been increasingly recorded in Western Ukraine, with their appearance being caused by human activities (KIRPAN \& SVERLOVA 2002, GURAL-SVERLOVA \& SAVCHUK 2019). The successful survival of species introduced from regions of warmer climate, in particular, from the south of Ukraine (BALASHOV et al. 2018, GURAL-SVERLOVA et al. 2019, GURAL-SvERLOVA \& GURAL 2017a, 2020, SverLova 1998 etc.), is also often observed. This can be facilitated by both the specific microclimate of urbanized biotopes, usually inhabited by such species, and global climate changes. It is possible that a species of western Mediterranean origin, Cornu aspersum (O. F. Müller, 1774), whose breeding on small (home) farms is becoming more and more popular in Ukraine, may be added to the number of such warm-loving invaders who have managed to adapt to the present climatic conditions of Western Ukraine.

Not long ago, we reviewed the records of $C$. aspersum on the territory of Ukraine known by that time, only one of which concerned the west of the country (GURAL-SvERLOVA \& GLEBA 2016). However, some findings of this species were made later in other parts of Ukraine, and were only partially published (LEONOV 2017) or entered into databases (INATURALIST 2021, UkrBIN 2021). Further, in the summer of 2021, live specimens of $C$. aspersum were found by us in two settlements of the Lviv region. And in the spring of 2020, regional mass media reported many dead individuals of $C$. aspersum, illegally dumped nearby another settlement. It was reported that live snails might have also been present, with a possibility to form another colony.

Therefore, the main objectives of this paper were: 1) to describe new findings of $C$. aspersum in Western Ukraine; 2) give a brief overview of the known records of this species in different parts of Ukraine with an assessment of the probability of the formation of established populations of C. aspersum in them; 3) to analyse the probable chronology and sources of penetration of other introduced species of land molluscs into Western Ukraine to assess whether the possible acclimatization of $C$. aspersum here fits into the general trend.

\section{Material und methods}

In the summer of 2021, we examined two sites in the Lviv region, where live specimens of $C$. aspersum were found: 1) Lviv, Zaklynskykh street, undeveloped area east of No. 9, 4951'00.8"N 2403'17.9"E, roadside, partly open, partly shaded by trees (Fig. 1), the first finding of C. aspersum on June 26, 2021, subsequent repeated surveys of the same site in late June - early July, the last two additional site visits on October 4 and 13, 2021;

2) Pustomyty district, Solonka village, the beginning of Ivan Sirko street, from the southern $\left(49^{\circ} 44^{\prime} 57.2^{\prime \prime N}\right.$ $\left.23^{\circ} 59^{\prime} 38.1^{\prime \prime E}\right)$ and eastern $\left(49^{\circ} 44^{\prime} 58.1^{\prime \prime} \mathrm{N} 23^{\circ} 59^{\prime} 39.8^{\prime \prime} \mathrm{E}\right)$ sides of the site previously used for snail farming, and then 
abandoned and overgrown with tall grass, two surveys on August 9 and 18, 2021. According to our preliminary observations, in 2019 , this site of approximately $30 \times 40 \mathrm{~m}$ was used for outdoor rearing of juveniles of $C$. aspersum to marketable size. In 2020, we did not explore Solonka due to quarantine during the Covid-19 pandemic, and in 2021 the site was already abandoned.

Additionally, on September 7, 2021, a site was surveyed north of Zhovkva, Zhovkva district, between $50^{\circ} 04^{\prime} 30.4^{\prime \prime} \mathrm{N}$ $23^{\circ} 59^{\prime} 28.6^{\prime \prime} \mathrm{E}$ and $50^{\circ} 04^{\prime} 29.3^{\prime \prime} \mathrm{N} 23^{\circ} 59^{\prime} 28.9^{\prime \prime} \mathrm{E}$, where the illegally discarded waste of an unknown snail farm (Fig 2A) was buried in the spring of 2020. By the time of the survey, most of the shells were covered with soil. When examining this additional site, we set ourselves the following goals: 1) to find live individuals that could have survived at the site since the last year (see Introduction) or may be the offspring of surviving snails; 2) to collect well-preserved empty shells, study their variability and pass them to the museum collection (see below). If a colony of $C$. aspersum is found soon at the studied site, the data obtained can be used to compare the conchological variability in potential founders and their descendants who have managed to adapt to the climatic conditions of the Lviv environs.

The shells of adults were measured according to the standard method using a calliper with an accuracy of $0.1 \mathrm{~mm}$. All such shells from Lviv and Solonka and 25 randomly selected shells collected near Zhovkva were measured. The results obtained were compared with the literature data on the shell height and width in C. aspersum (Table 1).

For shells with distinct dark spiral bands, phenotypes were scored, similar to Cepaea species (Clarke 1960). The bands were designated by Arabic numerals from 1 to 5, counting them from the apex to the base of the shell. The absence of the band was indicated as " 0 " in place of the corresponding numeral. The fusion of adjacent bands was indicated with parentheses.

The collected material is stored in the malacological collection of the State Museum of Natural History of the National Academy of Sciences of Ukraine in Lviv with the following inventory numbers: No. 4762 - Lviv, No. 4794 - Solonka, No. 4796 - Zhovkva.

To clarify the species composition of introduced land molluscs in different administrative regions of Western Ukraine, in addition to our data and literature sources mentioned in Table 2, we used some information from the monograph of BALASHOV (2016) and two databases (INATURALIST 2021, UkrBIN 2021). Data from the databases were used only in the case they were accompanied by high-quality photographs that allowed for reliable species identification, and our identifications did not always coincide with those indicated in the databases.

As in previous publications (GURAL-SVERLOVA \& SAVCHUK 2019, KirPan \& SVERlova 2002), we did not include in the list of introduced land molluscs of Western Ukraine (Table 2) three slug species, for which the exact boundaries of their natural ranges in Europe are not clear (KERNEY et al. 1983): Deroceras reticulatum (O. F. Müller, 1774), D. sturanyi (Simroth, 1894), and Arion fasciatus (Nilsson, 1823). In our opinion, the non-native origin of these spe- cies for the west and other parts of Ukraine is very likely, although BALASHOV (2016) expresses some doubts about this.

As in our other papers (GURAL-SvERLOVA et al. 2021, Gural-Sverlova \& GURAL 2020, 2021), we prefer to use the term "colony" rather than "population" to refer to an aggregation of individuals of C. aspersum or other introduced land molluscs found in a certain limited area. Often we are talking about recently formed isolated aggregations with a limited number of individuals. Therefore, it is not known whether they will be able to become established populations in the future, capable of maintaining their numbers for a long time, which is one of the population criteria.

\section{Results}

At the first studied site (Lviv), snails were concentrated mainly near the kerb, along a strip of crushed stone held together by cement (Fig. 1). Only one adult was found at a distance of about $4 \mathrm{~m}$ from the kerb, but in most cases, this distance did not exceed 1-2 m. The length of the site inhabited by $C$. aspersum was about $45 \mathrm{~m}$, although most of individuals were found at a section with a length of about $25 \mathrm{~m}$. The penetration of $C$. aspersum into the surrounding area, which is mostly densely overgrown with trees, has not yet been discovered.

In summer, snails of different ages (Fig. $3 \mathrm{~A}-\mathrm{C}$ ) were found mainly at the open part of the site, along the kerb or in the grass, less often along the kerb at the shaded part of the site. In early October, some adults and large immature individuals were found dormant on the outside of the kerb, but only at the shaded part of the site. There was no C. aspersum on the open grassy slope. The same pattern was observed in mid-October, a few days after the first frost on the grass and at low positive minimum temperatures at night (less than $5^{\circ} \mathrm{C}$ ). Taken in hand, all individuals of $C$. aspersum immediately began to show activity. During summer and autumn visits to the site, we found 8 other species of land molluscs, which are autochthonous or introduced for Western Ukraine. The first, smaller group included large snails Helix pomatia Linnaeus, 1758, H. lutescens Rossmässler, 1837, and Caucasotachea vindobonensis (C. Pfeiffer, 1828). The second group included Cepaea hortensis (O. F. Müller, 1774), Monacha cartusiana (O. F. Müller, 1774), Arion vulgaris Moquin-Tandon, 1855, Krynickillus melanocephalus Kaleniczenko, 1851, and Deroceras caucasicum (Simroth, 1901).

It can be noted that in summer $C$. aspersum was found at the site more often than the autochthonous snails $H$. pomatia and $H$. lutescens of comparable size, which also clearly gravitated to the open grassy slope and to the cement strip along the kerb. By mid-October, C. aspersum remained almost the only species of land molluscs at the site, with the exception of a single juvenile of Helix and two introduced slug species that breed in autumn $-K$. melanocephalus and D. caucasicum.

During the first two visits to the site in June 2021, we collected 6 adults and 25 juveniles, as well as one empty shell of an adult $C$. aspersum; later this material was passed 
to the museum collection (see Material and methods). On subsequent visits, we observed at the site a different number of adult and juvenile snails, from a few specimens to several dozen. Thus, in general, at least 50 live individuals of $C$. aspersum were observed at the site.

During two visits to Solonka, three adults and three juveniles of $C$. aspersum were found at a distance of no more than $1 \mathrm{~m}$ from the fence of the former site for the rearing of this species.

When examining the burial site of the snail farm waste near Zhovkva, a large number of $C$. aspersum shells were found; in some of them, partially decomposed bodies were preserved (Fig. 2B). Almost all shells were adults or large juveniles. However, three empty shells of the same species, about $1-1.5 \mathrm{~cm}$ wide (Fig. 2B right), were found in two large shells.

At all studied sites, large variability in the shell colouration of C. aspersum was recorded. Both in Lviv and in Solonka, individuals with different shell ground colours (yellowish or reddish horny) were found, which was better seen in juveniles (Fig. 4B, C). The degree of expression of the dark spiral bands on the shell was also very variable at both sites (Fig. 4A, D). In Lviv, about half of the collected snails had clearly visible wide bands, dark brown or almost black. Even in juveniles of relatively small size, the second and third bands were already partially (Fig. 3C) or completely (Fig. 4B, C) fused. In adults of this colouration type, phenotypes 1(23)45, 1(23)(45), (123)(45) were recorded.

The second half of the snails collected in Lviv had lighter and narrower bands, often poorly visible (especially in juveniles). On the shells of juveniles, it was noticeable that bands (especially the fourth and fifth) appear on the shell later than in snails with well-developed dark bands. All bands, even the second and third, were discrete not only in juveniles but also in some adults. In other adults, the second and third bands were partially fused.

A relationship between the ground colour of shells and the intensity of dark spiral bands on them was noted. Usually, the yellowish horny ground colour is accompanied by poorly developed, light bands, while the reddish horny ground colour is accompanied by well-developed dark bands. So, among 25 juveniles collected in Lviv (see above), the following combinations of these features were recorded:

13 individuals - yellowish horny shell and light, poorly visible bands (Fig. 4B left);

1 - yellowish horny shell and well-developed dark bands (Fig. 4C right);

1 - reddish horny shell and light, poorly visible bands (Fig. 4C left);

10 - reddish horny shell and well-developed dark bands (Fig. 4B right).

Empty shells collected near Zhovkva (Fig. 2B) lay in the soil for a long time, making it impossible to determine their ground colour. Most of the shells had clearly visible bands and phenotypes 12345 and 1(23)45. Phenotypes (123)45, 1(234)5, 10345 and a few shells with a poorly distinguishable spiral pattern and even completely without bands were also found.

\section{Discussion}

A large land snail of the western Mediterranean origin, C. aspersum, has been occasionally mentioned for different regions of Ukraine since the end of the 19th century, although until recently such single introductions did not lead to the formation of stable populations of this species there (Gural-Sverlova \& Gleba 2016). One of the earliest known references to $C$. aspersum for Ukraine is in the first catalogue of the malacological collection of the present State Museum of Natural History in Lviv (BĄKOWSKI 1891). It was about one shell collected in the vicinity of Vinnytsia (then a separate settlement called Piatnychany, now part of Vinnytsia) in Central Ukraine. This shell is still stored in the museum collection and, indeed, belongs to $C$. aspersum (Fig. 5A). Its primary label was without a year of collecting, but other samples from the same area were dated 1875 (Gural-Sverlova \& GlebA 2016). Unfortunately, it is not known how the samples from near Vinnytsia ended up in the Lviv museum. Indeed, at that time Vinnytsia and Lviv were in different countries, and the museum collections were of a distinctly regional character.

In several publications of the late 19th to early 20th centuries (LINDHOLM 1926, TAYLOR 1914, ZYKOV, 1890), there are references to the presence of $C$. aspersum in the southwest of Ukraine (in Odessa and Kherson), apparently based on one primary source (GURAL-SvERLOVA \& GLEBA 2016, LeONov 2017). Namely, TAYLOR (1914) refers to the findings of Dr H. Jordan, and LinDHOLM (1926) to ZYKov (1890). Unfortunately, we were unable to access the article by ZYKOV (1890). Apparently, solely on the basis of the above data, not only TAYLOR (1914) but almost a century later, WELTER-SCHULTES (2012) marked the southwest of Ukraine on their maps as a possible part of the range of $C$. aspersum, although neither from the middle to the second half of the 20th, nor at the beginning of the 21 st century, there was any new mention of the presence of $C$. aspersum there.

In 1909, LindHolm (1926) received several specimens of C. aspersum, collected a few years earlier alive in Feodosia (mountainous Crimea). Neither before nor after C. aspersum was found in Feodosia and in Crimea in general. Only in 2016, a colony of this species was recorded in the park of the sanatorium "Aivazovskoye" in Partenit, mountainous Crimea (Leonov 2017). A few years earlier, many rhododendrons, azaleas and other exotic ornamental plants were planted in the park. These were mainly plants brought from Tuscany in Italy, i.e. from the native range of $C$. aspersum. In 2017, the author of the cited paper collected 7 live adults of $C$. aspersum, 5 empty shells of adults, and about two dozen fragments and whole shells of juvenile snails in the park of the sanatorium.

The only evidence of the accidental delivery of $C$. aspersum into Western Ukraine, described so far, was also associated with Italy. These were two snails of this species (Fig. 5B), found in May and June 2014 inside a car bringing raw materials from the Italian town of Molvena to Vynohradiv, Transcarpathian region (GURAL-SvERLOVA \& GLEBA 2016). In this case, the snails not only did not form a viable colony but did not even manage to get into 
a suitable habitat. Therefore, we consider the subsequent inclusion of $C$. aspersum in the species list of land molluscs of the Transcarpathian region (BALASHOV 2016) to be premature. With respect to that, we believe that the colony of $C$. aspersum found by us in Lviv and described in this paper should actually be considered the first record of this species in Western Ukraine.

In recent years, $C$. aspersum breeding has become an increasingly popular form of small business in Ukraine. This increases the chances of some individuals accidentally entering suitable habitats with the subsequent formation of colonies there. A striking example of this represents the finding of C. aspersum in the summer of 2021 in the Bila Tserkva district of the Kyiv region (INATURALIST 2021, UKrBIN 2021). The snails found by S. Oksenenko in the forest near the Shkarivka village had a very dark (black) mantle edge (Fig. 5C). This trait is characteristic of the large form of $C$. aspersum bred on farms under the name "Maxima" - in contrast to the smaller form with a light mantle edge, which farmers have given the distorted name "Muller". Until now, only snails with a light mantle edge have been found in Western Ukraine (Fig. 3B, E, 5B).

Farm-raised snails are likely to adapt more quickly and better to the local climate, as a large part of their life cycle on a farm is usually outdoors. Therefore, the most critical here may be, obviously, the overwintering and the survival rate of snails recently hatched from eggs (on farms such individuals are kept in hothouses). However, the microclimate of urbanized areas, where introduced species of land molluscs are most often recorded (SvERLova et al. 2006), is characterized by smoother temperature fluctuations and less severe winters.

An equally effective source of $C$. aspersum penetration into the territory of Ukraine and its western part may be the accidental delivery with cultivated plants (LEONov 2017), which is common for invasive species of land molluscs. In this case, the main role in the dispersal of alien species belongs to garden centres, which import a significant part of the sold seedlings from other European countries and practically uncontrollably (GURAL-SVERLOVA et al. 2021). Vivid examples of this are the recent rapid dispersal of a large pest slug Arion vulgaris Moquin-Tandon, 1855 across the territory of Ukraine (UKRBIN 2021) and the increasing records of Cepaea nemoralis (Linnaeus, 1758) in different parts of the country (GURAL-SvERLOva et al. 2021).

Considering the large size and beautifully coloured shells of $C$. aspersum, this species can be also an attractive object for deliberate resettlement by humans. In particular, large and beautiful snails can be moved over relatively short distances within the same settlement during children's play, which we have already discussed with the example of C. hortensis (SVERLova 2002).

Assessing the climatic conditions of the western and other parts of Ukraine, not so long ago we suggested that the appearance and possible future establishment of $C$. aspersum populations should be expected primarily in the Crimea, and in Western Ukraine - in the Transcarpathian region (Gural-Sverlova \& Gleba 2016). The first assumption was almost immediately confirmed by the above-men- tioned record in Partenit (Leonov 2017). There are still no data on new findings of $C$. aspersum in the Transcarpathian region. However, $C$. aspersum has recently been increasingly recorded in the cities of Central Europe, including Slovakia and Hungary adjacent to the Transcarpathian region of Ukraine (ČEJKA et al. 2020, 2021, PÁLL-GERGELY et al. 2019, etc.).

It is possible that in the near future $C$. aspersum can become a more or less common representative of the land malacofauna of urbanized and suburbanized areas not only in Transcarpathia but also in other administrative regions of Western Ukraine. This may be indicated by the recent findings of $C$. aspersum in the Lviv region, described in this paper. Individuals of $C$. aspersum of different ages were found both in Lviv and in Solonka. This probably indicates the successful reproduction and overwintering of snails at recently populated and still small sites.

So far we have not been able to find live specimens of C. aspersum near Zhovkva. However, it cannot be completely excluded that several small shells (Fig. 2B right) found in empty shells of adults of $C$. aspersum belonged to snails that hatched from eggs at the site studied by us. In such empty shells, several live juveniles and empty shells of another introduced land snail living at this site, C. hortensis, were also found. It is likely that young snails use larger and thicker empty shells of their own or another species as shelter, but under unfavourable conditions, they can die in them.

However, the final question of how well the Mediterranean species $C$. aspersum will be able to adapt to the climatic conditions of the Lviv region is impossible to answer without further long-term observations of the colonies that have already been found and those that are likely to be found in the future. It will be necessary to pay attention not only to the long-term survival of snails and the gradual expansion of the sites inhabited by them. Such survival in climatic conditions not entirely favourable for introduced species far beyond their native ranges, may be accompanied by some changes in size, shape, or especially in the colouration of their shells (GURAL-SvERLOva \& Gural 2018, Sverlova et al. 2006). Since C. aspersum has a large variability of shell colouration, including at the sites studied by us (Fig. 3, 4), observation of possible changes in the phenotypic structure of newly formed colonies may be of particular interest.

The shell sizes of the adults of $C$. aspersum, collected in Western Ukraine and measured by us, are well within the ranges of the variability of these sizes indicated in the literature (Table 1). On average, the shells of snails raised on the farm (Zhovkva) turned out to be slightly larger than those of individuals of the same species from Lviv and especially from Solonka. However, the number of collected adults in the last two cases was too small to obtain statistically significant results.

Taking into account $C$. aspersum and our (not yet published) first record of Monacha claustralis (Rossmässler, 1834) in Western Ukraine (Lviv), at least 22 introduced species of land molluscs are already known for this area (Table 2). It is likely that three species of slugs with unclear boundaries of their native ranges, mentioned in the 
Material and methods, should also be added to them. The largest number of introduced species was recorded in Lviv. On the one hand, this may partially depend on the intensity of the malacological studies carried out there. On the other hand, which seems to be more likely, Lviv is the largest city in Western Ukraine, with intensive transport and trade links both with other regions of Ukraine and with other European countries. Quite a large number of alien species were also recorded in the Transcarpathian region (Table 2), which is obviously caused by the warmer climate of the Transcarpathian lowland.

Despite the large species diversity of introduced land molluscs that are now found in Western Ukraine, most of them apparently penetrated there in the late 20th or early 21 st century (Table 2). This could be facilitated by both global climatic changes and the end of a strong economic decline in Ukraine in the 1990s, after which an active and almost uncontrolled import of seedlings of the garden and ornamental plants from other European countries began (GURAL-SVERLOVA et al., 2021).

The importance of climatic changes can be especially evidenced by the fact that it was during this period of time that species began to be recorded in Western Ukraine, which until relatively recently were found only in the south of the country (listed in the order of their first findings, according to Table 2): Monacha cartusiana (O. F. Müller, 1774), Brephulopsis cylindrica (Menke, 1828), Xeropicta derbentina (Krynicki, 1836), Tandonia kusceri (Wagner, 1931), Monacha fruticola (Krynicki, 1833). This group may also include two slug species of Caucasian origin, Krynickillus melanocephalus Kaleniczenko, 1851 and Deroceras caucasicum (Simroth, 1901). Until the end of the 20th century, they were known in Ukraine only from the Crimea (Likharev \& WiKToR 1980), although their native ranges may include possibly also the Donetsk Upland in the east of Ukraine, which was practically not studied at that time by malacologists.

The presence of such a number of more southerly species of land molluscs that have successfully acclimatized in Western Ukraine in recent decades may indicate the possibility of the population establishment of $C$. aspersum here in the future. However, only further research can confirm this assumption.

\section{Acknowledgements}

We are grateful to S. Oksenenko, V. Gleba, and M. Myroslav for the information on some findings of $C$. aspersum in Central and Western Ukraine and permission to use their photographs.

\section{References}

BAIDASHNIKOV A. A., 1985: Наземные моллюски Закарпатской области и их распространение по основным ландшафтам и растительным сообществам [Land molluscs of the Transcarpathian region and their distribution in connection with main landscaps and plant asociations]. - Trudy Zoologicheskogo instituta AN SSSR, 135: 44-66. (in Russian)

BĄKOWSKi J., 1884: Mięczaki galicyjskie [Molluscs of Galicia]. - Kosmos, 9: 190-197, 275-283, 376-391, 477-490, 604-611,
680-697, 761-789. (in Polish)

BĄKowski J., 1891: Mięczaki (Mollusca) [Molluscs (Mollusca)]. - Wydawnictwo Muzeum im. Dzieduszyckich, Lwów, 264 pp. (in Polish)

BALASHOV I. O., 2016: Охрана наземных моллюсков Украины [Conservation of terrestrial molluscs in Ukraine]. - I.I.Schmalhausen Institute of Zoology, Kyiv, 272 pp. ISBN 978-966-027841-7 (in Russian)

Balashov I. O., Baidashnikov A. A., Romanov G. A. \& Gural-Sverlova N. V., 2013: Наземные моллюски Хмельницкой области (Подольская возвышенность, Украина) [Terrestrial molluscs of Khmelnitsky region (the Podolian Upland, Ukraine)]. - Zoologicheskij Zhurnal, 92(2): 154-166. https://doi.org/10.7868/s0044513413020037 (in Russian)

Balashov I., Kramarenko S., Shyriaieva D. \& Vasyliuk O., 2018: Invasion of a Crimean land snail Brephulopsis cylindrica into protected relict steppic hilltops (tovtrs) in Western Ukraine: a threat to native biodiversity? - Journal of Conchology, 43(1): 59-69.

Čejka T., Beran L., Korábek O., Hlaváč J. Č., HoráčKová J., Coufal R., Drvotová M., Mañas M., Horsáková V. \& Horsák M., 2020: Malacological news from the Czech and Slovak Republics in 2015-2019. - Malacologica Bohemoslovaca, 19: 71-106.

Čejka T., Beran L., Coufal R., DvořáK L., Hlaváč J. Č., HoráčKová J., Horsáková V., JuřičKová L., Kosová T., ČaČanÝ J., Szabóová D., Ř́nová D., Tej B. \& Horsák M., 2021: Malacological news from the Czech and Slovak Republics in 2020. - Malacologica Bohemoslovaca, 20: 56-74. https://doi.org/10.5817/MaB2021-20-56

Clarke B. C., 1960: Divergent effects of natural selection on two closely-related polymorphic snails. - Heredity, 14(3-4): 423-443. https://doi.org/10.1038/hdy.1960.39

GARbar A. V. \& Chernyshova T. N., 2011: Клональная изменчивость Limax flavus (Pulmonata, Limacidae): аллозимный, кариологический и морфологический анализ [Clonal variability of Limax flavus (Pulmonata, Limacidae): allozyme, karyologycal and morphological analysis]. - Vestnik zoologii, 45(1): 3-9. (in Russian)

Gural-Sverlova N., Egorov R., Kruglova O., Kovalevich N. \& Gural R., 2021: Introduced land snail Cepaea nemoralis (Gastropoda: Helicidae) in Eastern Europe: spreading history and the shell colouration variability. - Malacologica Bohemoslovaca, 20: 75-91. https://doi.org/10.5817/MaB2021-20-75 Gural-Sverlova N. V. \& Gleba V. N., 2016: Evidence of the repeated penetration of Cryptomphalus aspersa (Gastropoda, Pulmonata, Helicidae) into the territory of Eastern Europe. Russian Journal of Biological Invasions, 7(2): 146-151. https:// doi.org/10.1134/S2075111716020077

Gural-Sverlova N., Gleba V. \& Gural R., 2019: Einschleppung von Tandonia kusceri (Pulmonata: Milacidae) nach Transkarpatien und Verbreitung von Tandonia-Arten in der Ukraine [Introduction of Tandonia kusceri (Pulmonata: Milacidae) in Transcarpathian and distribution of Tandonia species in Ukraine]. - Malacologica Bohemoslovaca, 18: 19-26. (in German)

Gural-Sverlova N. V. \& Gural R. I., 2011: Arion lusitanicus (Gastropoda, Pulmonata) на западе Украины [Arion lusitanicus (Gastropoda, Pulmonata) in Western Ukraine]. - Vestnik zoologii, 45(2): 173-177. (in Russian)

GuRAL-Sverlova N. V. \& GuRal R. I., 2016: Новые находки слизней Arion distinctus и Arion circumscriptus (Arionidae) на территории Украины [New findings of the slugs Arion distinctus and Arion circumscriptus (Arionidae) in the territory of Ukraine]. - Ruthenica, 26(1): 17-23. (in Russian)

Gural-Sverlova N. V. \& Gural R. I., 2017a: Expansion of 
the ranges of land mollusks of the genus Xeropicta (Gastropoda, Hygromiidae) in Ukraine. - Russian Journal of Biological Invasions, 8(3): 212-217. https://doi.org/10.1134/ S2075111717030043

Gural-Sverlova N. V. \& Gural R. I., 2017b: Наземные моллюски Oxychilus draparnaudi и Oxychilus cf. mortilleti (Gastropoda, Pulmonata, Zonitidae) на территории Украины [The land snails, Oxychilus draparnaudi and Oxychilus cf. mortilleti (Gastropoda, Pulmonata, Zonitidae) in the territory of Ukraine]. - Zoologicheskij Zhurnal, 96(4): 375-382. https://doi.org/10.7868/s0044513417020039 (in Russian)

Gural-Sverlova N. V. \& Gural R. I., 2018: Многолетняя динамика фенетической структуры в колониях интродуцированного вида Cepaea hortensis (Gastropoda, Pulmonata, Helicidae) [Long-term dynamic of phenetic structure in colonies of the introduced species, Cepaea hortensis (Gastropoda, Pulmonata, Helicidae)]. - Zoologicheskij Zhurnal, 97(7): 751-761. https://doi.org/10.1134/s0044513418070097 (in Russian)

Gural-Sverlova N. V. \& Gural R. I., 2020: First records of the land snail Monacha fruticola (Gastropoda, Stylommatophora, Hygromiidae) in Western Ukraine. - Zoodiversity, 54(2): 95-98. https://doi.org/10.15407/zoo2020.02.095

Gural-Sverlova N. V. \& GuRAL R. I., 2021: Shell banding and colour polymorphism of introduced snail Cepaea hortensis (Gastropoda, Pulmonata, Helicidae) from some parts of Eastern Europe. - Ruthenica, 31(2): 59-76. https://doi.org/10.35885/ruthenica.2021.31(2).2

Gural-Sverlova N. V., Gural R. I. \& Savchuk S. P., 2020: Новые находки Cераea nemoralis (Gastropoda, Pulmonata, Helicidae) и фенетическая структура колоний этого вида на западе Украины [New records of Cepaea nemoralis (Gastropoda, Pulmonata, Helicudae) and phenotypic composition of its colonies in Western Ukraine]. - Ruthenica, 30(2): 75-86. https://doi.org/10.35885/ruthenica.2021.30(2).1 (in Russian)

Gural-Sverlova N. V. \& Savchuk S. P., 2019: Антропохорні види наземних молюсків на заході України [Anthropochorous species of land molluscs in Western Ukraine]. - Naukovi zapysky Derzhavnoho pryrodoznavchoho muzeiu, 35: 49-58. https://doi.org/10.36885/nzdpm.2019.35.49-58 (in Ukrainian)

INATURAList, 2021: iNaturalist: A Community for Naturalist. Online at http://www.inaturalist.org, accessed at September 19, 2021.

KANtoR Yu. I. \& Sysoev A. V., 2005: Каталог моллюсков России и сопредельных стран [Catalogue of molluscs of Russia and adjacent countries]. - KMK Scientific Press Ltd., Moscow, 627 pp. ISBN 5-87317-191-2 (in Russian)

Kerney M. P., Cameron R. A. D. \& Jungbluth J. H., 1983: Die Landschnecken Nord- und Mitteleuropas [Land molluscs of Northern and Central Europe]. - Parey, Hamburg-Berlin, 384 pp. ISBN 3-490-17918-8 (in German)

Kirpan S. P. \& Sverlova N. V., 2002: До вивчення синантропних елементів у наземних малакоценозах заходу України [To the study of synanthropic elements in land mollusc communities of Western Ukraine]. - Naukovi zapysky Derzhavnoho pryrodoznavchoho muzeiu, 17: 191-195. (in Ukrainian)

LeONov S. V., 2017: Инвазивный вид Cornu aspersum (Mollusca: Pulmonata) в Крыму: первая находка после 1909 года и некоторые соображения по поводу этого события [Invasive species Cornu aspersum (Mollusca: Pulmonata) in the Crimea: the first record after 1909 and some considerations about this event]. - Ekosistemy, 10: 42-51. (in Russian)

LikhaRev I. M. \& Wiktor A. J., 1980: Слизни фауны CCCP и сопредельных стран (Gastropoda terrestria nuda) [Slugs from the fauna of the USSR and neighbouring countries (Gastropoda terrestria nuda)]. - Fauna of the USSR. New series, 122. Molluscs, 3(5). Nauka, Leningrad, 438 pp. (in Russian)

LindHOLm W. A., 1926: Ein Beitrag zur Kenntnis der Molluskenfauna der Krim [A contribution to the knowledge of the mollusc fauna of the Crimea].- Archiv für Molluskenkunde, 58: 161-177. (in German)

Páll-Gergely B., Majoros G., Domokos T., Juhácz A., TuróCi Á., Badacsonyi L., Fekete J. \& Asami T., 2019: Realtime Social Networking Service rapidly reveals distribution of non-ingenious land snails in a European capital. - BioInvasions Records, 8(4): 782-792. https://doi.org/10.3391/bir.2019.8.4.06 Polevina А. А., 1959: К фауне наземных моллюсков Закарпатья [To the fauna of land molluscs of Transcarpathia]. - Dokladyi i soobscheniya Uzhgorodskogo gosudarstvennogo universiteta. Seriya biologicheskaya, 3: 65-68. (in Russian)

SCHILеүко A. А., 1978: Наземные моллюски надсемейства Helicoidea [Land molluscs of the superfamily Helicoidea]. Fauna of the USSR. New series, 117. Molluscs, 3(6). Nauka, Leningrad, 384 pp. (in Russian)

SVERlova N. V., 1998: Знахідка Brephulopsis cylindrica (Gastropoda, Buliminidae) у Львові [First record of Brephulopsis cylindrica (Gastropoda, Buliminidae) in Lviv]. - Vestnik zoologii, 32(5-6): 72. (in Ukrainian)

Sverlova N. V., 2002: Влияние антропогенных барьеров на фенотипическую структуру популяций Cepaea hortensis (Gastropoda, Pulmonata) в условиях города [The influence of anthropogenic barriers on phenotypical structure of populations of Cepaea hortensis (Gastropoda, Helicidae) under urban conditions]. - Vestnik zoologii, 36(5): 61-64. (in Russian)

Sverlova N. V., Khlus L. N., Kramarenko S. S., Son M. O., Leonov S. V., Korol E. N., Vychalkovskaya N. V., ZemogLyadChuK K. V., Kirpan S. P., KuZ'movych M. L., Sten'ko R. P., Ferenz O. G., Shklyaruk A. N. \& Gural R. I., 2006: Фауна, экология и внутривидовая изменчивость наземных моллюсков в урбанизированной среде [Fauna, ecology and intraspecific variability of land molluscs under urban conditions]. State Museum of Natural History, Lviv, 226 pp. ISBN 966-02-4006-6 (in Russian)

TAYLOR J. W., 1914: Monograph of the land \& freshwater Mollusca of British Isles. Zonitidae, Endodontidae. Helicidae. Taylor brothers, Leeds, 522 pp. https://doi.org/10.5962/bhl. title. 13226

UkrBIN, 2021: UkrBIN: Ukrainian Biodiversity Information Network [public project \& web application]. - Online at http:// www.ukrbin.com, accessed at September 19, 2021.

Welter-SChultes F., 2012: European non-marine molluscs, a guide for species identification. - Planet Poster Editions, Göttingen, 679 pp. ISBN 3-933922-75-5

ZyкоV V. P., 1890: О географическом распространении наземных и пресноводных слизняков Европейской России [About the geographical distribution of land and freshwater molluses in European Russia]. - Vestnik estestvoznaniya, 5: 391-396. (in Russian) 


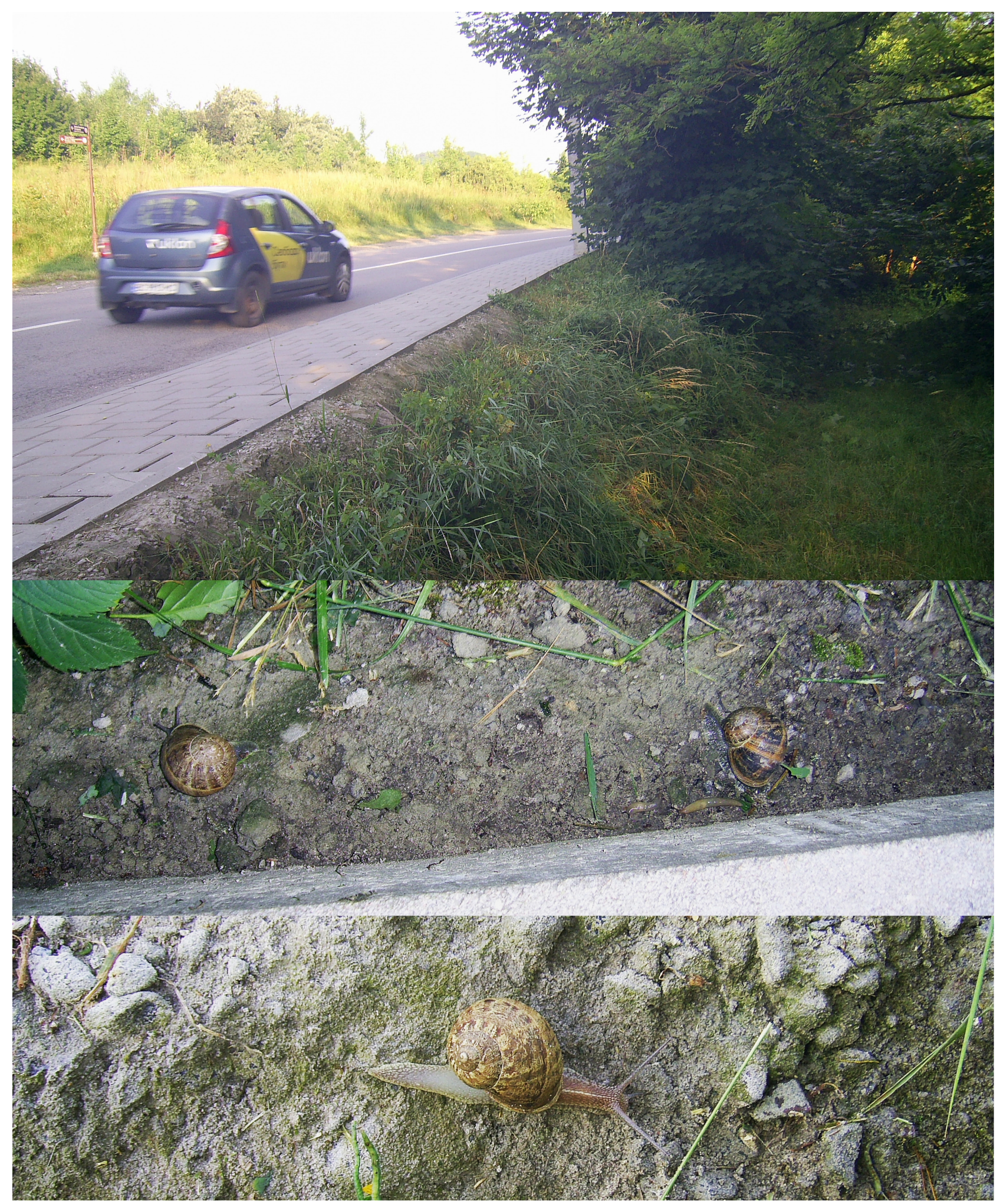

Fig. 1. Habitat of C. aspersum in Lviv. Photos by N. Gural-Sverlova. 


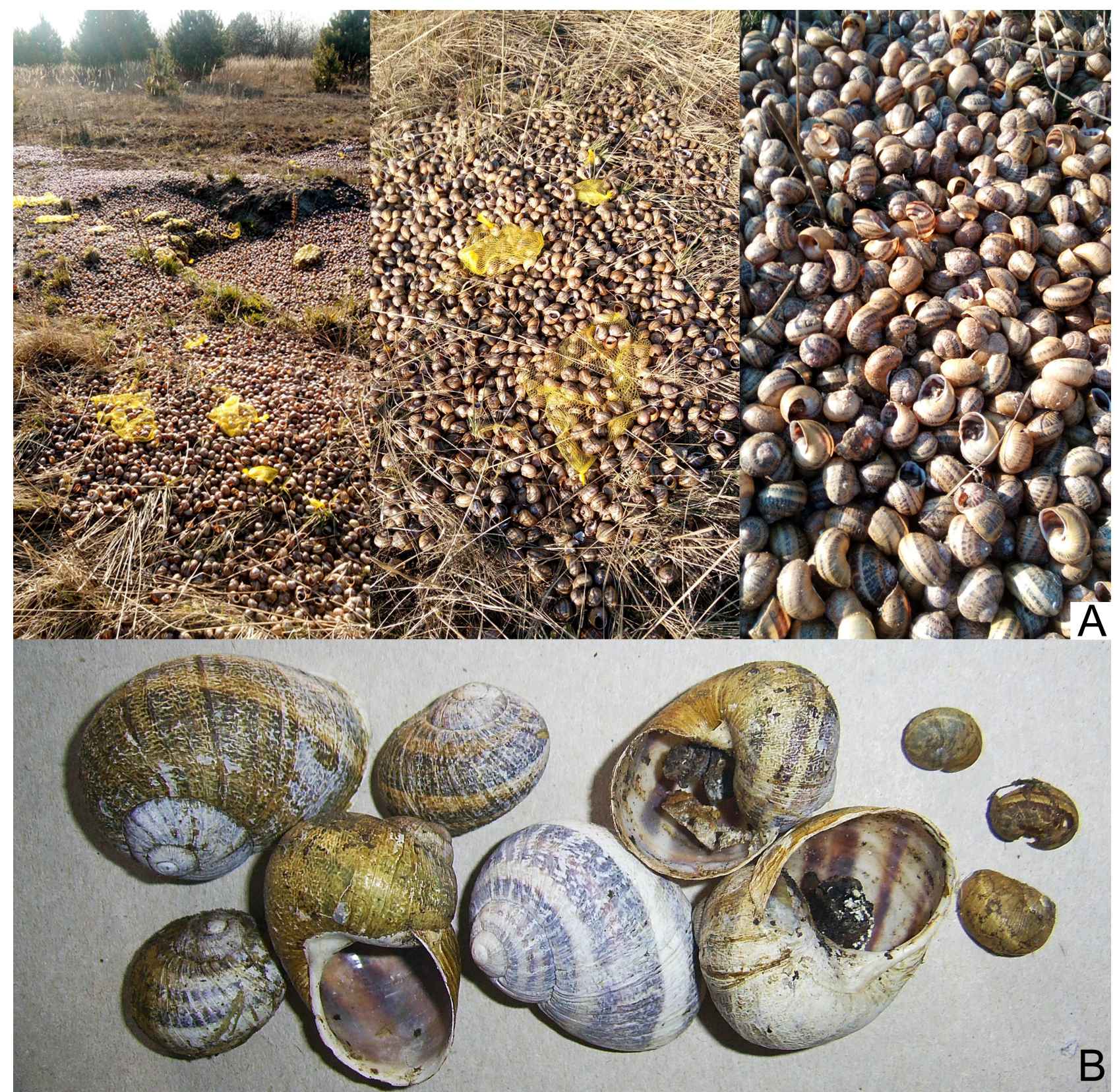

Fig. 2. C. aspersum near Zhovkva, Lviv region: A - illegal dump found in April 2020 (photos by M. Myroslav); B - empty shells and shells with partially decomposed bodies, collected at the same site in September 2021 (photo by N. Gural-Sverlova).

Table 1. Shell sizes of Cornu aspersum collected in Western Ukraine in comparison with literature data. Legend: N - number of measured adults, ${ }^{*}$ - shells of snails raised on a farm and discarded near the town, see Material and methods.

\begin{tabular}{|l|c|c|c|c|c|c|c|}
\hline Localities or references & \multirow{2}{*}{$\mathrm{N}$} & \multicolumn{9}{c|}{ Shell height } & \multicolumn{3}{c|}{ Shell width } \\
\cline { 3 - 8 } & & mean & $\min$ & $\max$ & mean & $\min$ & $\max$ \\
\hline \multicolumn{8}{|c|}{ Western Ukraine } \\
\hline Lviv & 7 & $32.3 \pm 0.36$ & 30.6 & 34.4 & $36.5 \pm 0.56$ & 34.0 & 40.0 \\
\hline Solonka & 3 & $30.1 \pm 0.05$ & 30.0 & 30.3 & $33.8 \pm 0.20$ & 31.8 & 35.3 \\
\hline *Zhovkva & 25 & $34.6 \pm 0.32$ & 31.2 & 37.7 & $39.2 \pm 0.41$ & 35.7 & 42.6 \\
\hline \multicolumn{8}{|c|}{ Literature data } \\
\hline (KeRNEY et al. 1983) & - & - & 20 & 40 & - & 25 & 45 \\
\hline (SCHILEYKo 1978) & - & - & 27 & 35 & - & 27 & 38 \\
\hline (WeLTER-SCHULTES 2012) & - & - & 30 & 35 & - & 32 & 40 \\
\hline
\end{tabular}




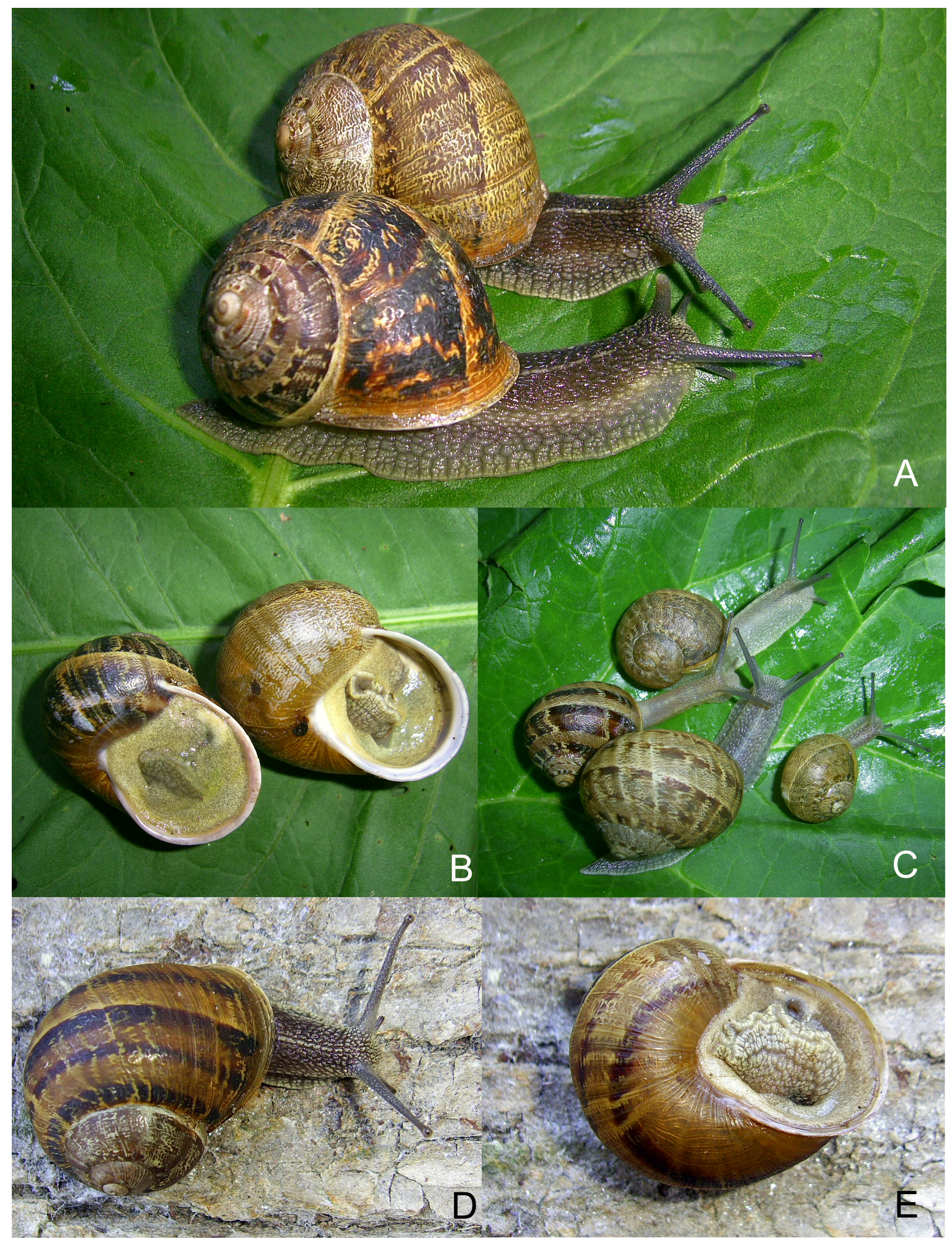

Fig. 3. Adults (A, B, D, E) and juveniles (C) of C. aspersum from Lviv region: A-C - Lviv; D, E - Solonka. Photos by N. Gural-Sverlova. 

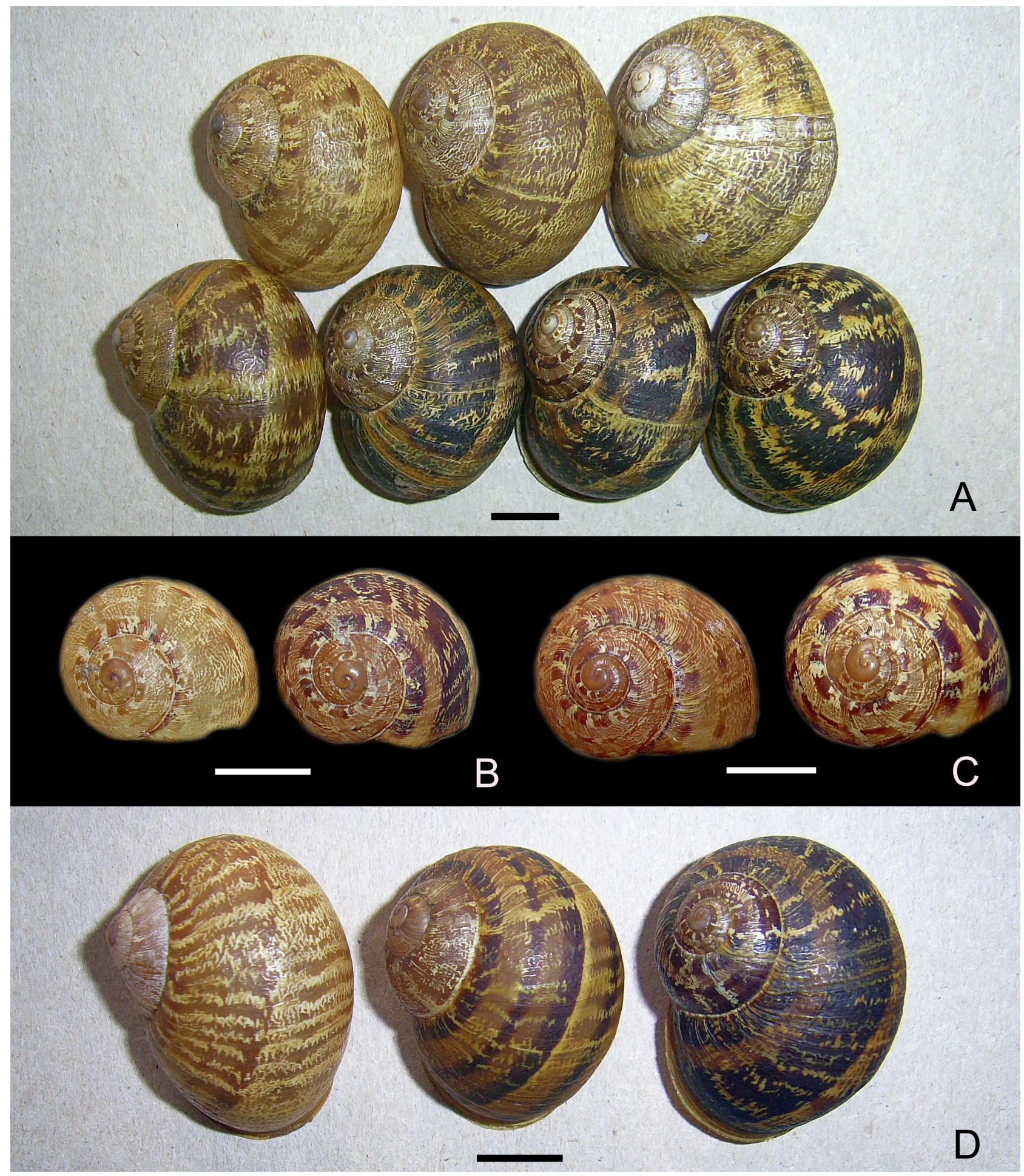

Fig. 4. Variability in shell colouration of adults $(\mathrm{A}, \mathrm{D})$ and juveniles $(\mathrm{B}, \mathrm{C})$ of $C$. aspersum from Lviv region: A-C - Lviv; D - Solonka; B - typical combination of ground colour and band intensity; C - untypical combination of ground colour and band intensity. Scale bars $1 \mathrm{~cm}$. Photos by N. Gural-Sverlova. 

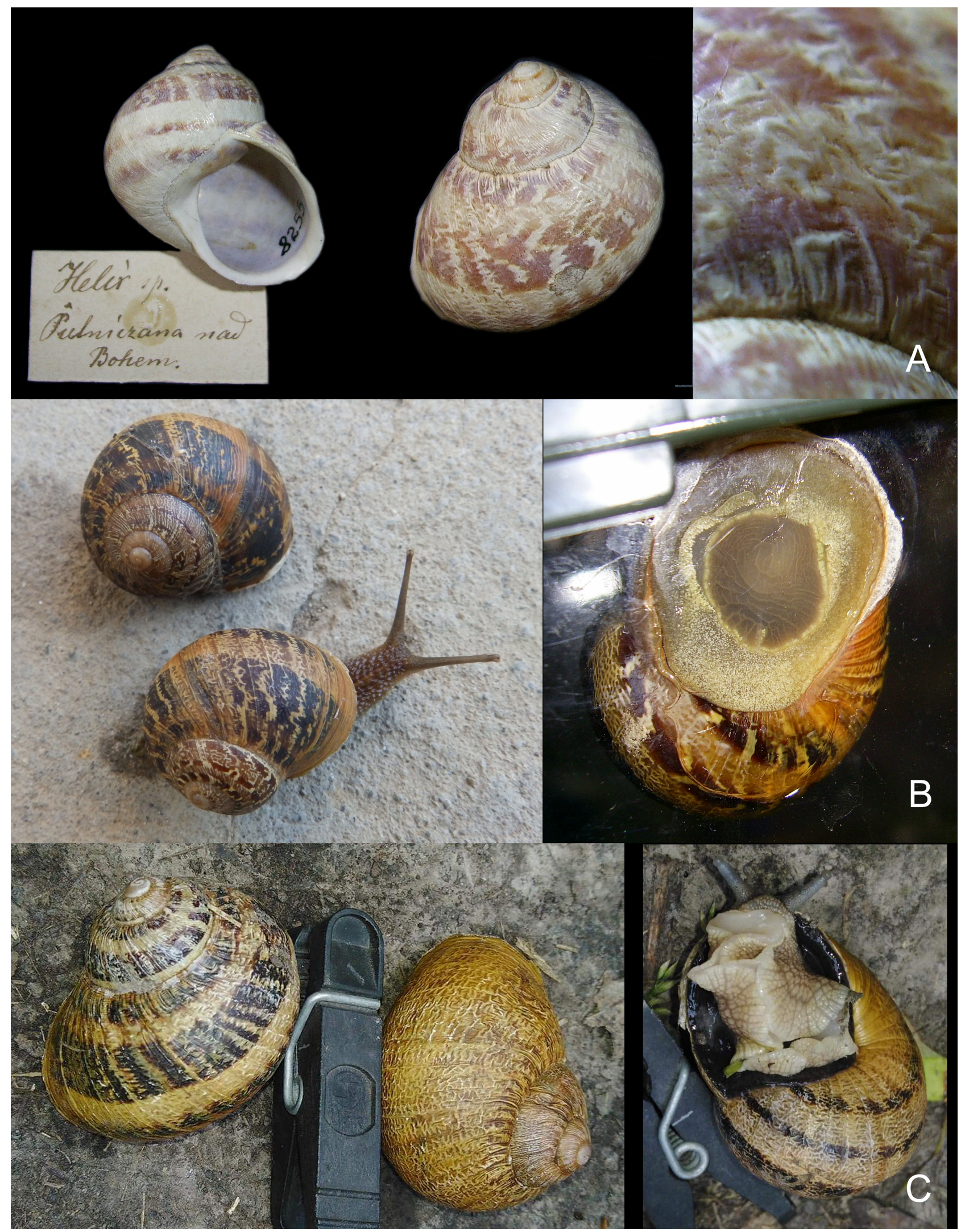

Fig. 5. Findings of $C$. aspersum from different parts of Ukraine: A - near Vinnytsia, 1875 (malacological collection of the State Museum of Natural History in Lviv, No. 89, photos by N. Gural-Sverlova); B - Vynohradiv, Transcarpathian region, 2014 (photos by V. Gleba on the left and N. Gural-Sverlova on the right); C - Shkarivka, Kyiv region, 2021 (photos by S. Oksenenko). 
Table 2. Introduced species of land molluscs in Western Ukraine. Abbreviations: $\mathrm{Ch}$ - Chernivtsi region; IF - Ivano-Frankivsk region; Kh - Khmelnytsky region; Lv - Lviv region excluding Lviv; Ri - Rivne region; TC - Transcarpathian region; Te - Ternopil region; Vo - Volyn region; (+) - identified as a Monacha cartusiana only by shell, so theoretically could refer also to another species, M. claustralis; ? - doubtful or requiring additional confirmation.

\begin{tabular}{|c|c|c|c|c|c|c|c|c|c|c|}
\hline \multirow[t]{2}{*}{ Species } & \multirow[t]{2}{*}{ Lviv } & \multicolumn{8}{|c|}{ Administrative regions } & \multirow[t]{2}{*}{ Time of first records, other remarks } \\
\hline & & $\mathrm{Ch}$ & IF & $\mathrm{Kh}$ & $\mathrm{Lv}$ & $\mathrm{Ri}$ & TC & $\mathrm{Te}$ & Vo & \\
\hline $\begin{array}{l}\text { Limax maximus } \\
\text { Linnaeus, } 1758\end{array}$ & + & + & + & + & + & + & + & + & + & $\begin{array}{l}\text { Possibly already in the second half of the 19th } \\
\text { century (BAKKOWSKI 1884, 1891) }\end{array}$ \\
\hline $\begin{array}{l}\text { Arion distinctus } \\
\text { Mabille, } 1868\end{array}$ & + & - & + & + & + & - & + & - & - & $\begin{array}{l}\text { Possibly already in the second half of the 19th } \\
\text { century (BACKOWSI 1884, 1891); reliably in } \\
1969 \text { near Uzhgorod, as Arion hortensis Féru- } \\
\text { ssac, } 1819 \text { (LIKHAREV \& WiKTOR 1980). Review } \\
\text { of other records in Ukraine (GURAL-SvERLOVA \& } \\
\text { GURAL 2016). }\end{array}$ \\
\hline $\begin{array}{l}\text { Cepaea nemoralis } \\
\text { (Linnaeus, } 1758 \text { ) }\end{array}$ & + & - & + & + & + & + & - & + & + & $\begin{array}{l}\text { An unsuccessful attempt to introduce to Lviv in } \\
\text { 1892, reliably since } 1994 \text {. In recent years, recor- } \\
\text { ded in a number of other settlements (GURAL- } \\
\text {-SVERLOVA et al. 2020, 2021). }\end{array}$ \\
\hline $\begin{array}{l}\text { Boettgerilla pallens } \\
\text { Simroth, } 1912\end{array}$ & + & + & + & - & + & - & - & - & - & $\begin{array}{l}\text { First mentioned for Lviv in the second half of the } \\
\text { 20th century (LIKHAREV \& WIKTOR 1980). }\end{array}$ \\
\hline $\begin{array}{l}\text { Tandonia cristata } \\
\text { (Kaleniczenko, } \\
\text { 1851) }\end{array}$ & - & - & - & - & - & - & + & - & - & $\begin{array}{l}\text { The only record near Uzhgorod without collecti- } \\
\text { on date (LIKHAREV \& WiKTOR 1980). }\end{array}$ \\
\hline $\begin{array}{l}\text { Cepaea hortensis } \\
\text { (O. F. Müller, 1774) }\end{array}$ & + & + & + & + & + & + & + & - & + & $\begin{array}{l}\text { No later than the end of 1970s in Lviv (GURAL- } \\
\text {-SVERLOVA \& GURAL 2021). }\end{array}$ \\
\hline $\begin{array}{l}\text { Lucilla singleyana } \\
\text { (Pilsbry, 1889) }\end{array}$ & - & - & - & - & - & - & + & - & - & $\begin{array}{l}\text { The only record in } 1982 \text { or } 1983 \text { near Vyno- } \\
\text { hradiv, Transcarpathian region (BAIDASHNIKov } \\
\text { 1985). }\end{array}$ \\
\hline $\begin{array}{l}\text { Monacha } \\
\text { cartusiana } \\
\text { (O. F. Müller, 1774) }\end{array}$ & + & $(+)$ & + & $(+)$ & + & $(+)$ & $(+)$ & - & $(+)$ & $\begin{array}{l}\text { First recorded in } 1990 \text { in Mukachevo, Transcar- } \\
\text { pathian region; since } 2000 \text { known for Lviv and } \\
\text { Lviv region (KIRPAN \& SverLOva 2002). Re- } \\
\text { cently, there has been a rapid dispersal of this } \\
\text { species in Western Ukraine. }\end{array}$ \\
\hline $\begin{array}{l}\text { Oxychilus } \\
\text { draparnaudi } \\
\text { (Beck, 1837) }\end{array}$ & + & - & - & - & + & - & + & - & - & $\begin{array}{l}\text { Recorded in the mid-1990s in Lviv (KIRPAN \& } \\
\text { SvERLOVA 2002). Later, this species was also } \\
\text { mentioned for Uzhgorod, but without a date } \\
\text { (KANTOR \& SYSOEV 2005). Review of records } \\
\text { in Ukraine (GURAL-SvERLOVA \& GURAL 2017b). }\end{array}$ \\
\hline $\begin{array}{l}\text { Aegopinella nitidula } \\
\text { (Draparnaud, 1805) }\end{array}$ & + & - & - & - & - & - & - & - & - & $\begin{array}{l}\text { Reliably registered only in Lviv, since the mid- } \\
\text {-1990s. (GURAL-SvERLOVA \& SAVCHUK 2019). }\end{array}$ \\
\hline $\begin{array}{l}\text { Brephulopsis } \\
\text { cylindrica } \text { (Menke, } \\
\text { 1828) }\end{array}$ & + & - & - & + & - & - & - & - & - & First recorded in 1998 in Lviv (SvERLova 1998). \\
\hline $\begin{array}{l}\text { Krynickillus mela- } \\
\text { nocephalus Kale- } \\
\text { niczenko, } 1851\end{array}$ & + & + & + & + & + & + & + & - & - & $\begin{array}{l}\text { First recorded in } 2000 \text { in Lviv (KIRPAN \& SVER- } \\
\text { LOVA 2002). }\end{array}$ \\
\hline $\begin{array}{l}\text { Harmozica } \\
\text { ravergiensis } \\
\text { (Férussac, 1835) }\end{array}$ & - & - & - & - & - & - & - & + & - & $\begin{array}{l}\text { The only finding near a quarry in the Ternopil } \\
\text { region in } 2006 \text { (GURAL-SvERLOVA \& SAVCHUK } \\
\text { 2019). }\end{array}$ \\
\hline $\begin{array}{l}\text { Arion vulgaris } \\
\text { Moquin-Tandon, } \\
1855\end{array}$ & + & + & + & + & + & + & + & + & + & $\begin{array}{l}\text { Recorded in } 2007 \text { near Lviv (GURAL-SvERLOVA } \\
\text { \& GURAL 2011). Perhaps it appeared in Uzhgo- } \\
\text { rod at the end of the 20th century (GURAL-SvER- } \\
\text { LOVA \& SAVCHUK 2019). }\end{array}$ \\
\hline
\end{tabular}


Table 2. Continued.

\begin{tabular}{|c|c|c|c|c|c|c|c|c|c|c|}
\hline \multirow[t]{2}{*}{ Species } & \multirow[t]{2}{*}{ Lviv } & \multicolumn{8}{|c|}{ Administrative regions } & \multirow[t]{2}{*}{ Time of first records, other remarks } \\
\hline & & $\mathrm{Ch}$ & IF & $\mathrm{Kh}$ & Lv & $\mathrm{Ri}$ & TC & $\mathrm{Te}$ & Vo & \\
\hline $\begin{array}{l}\text { Limacus flavus } \\
\text { Linnaeus, } 1758\end{array}$ & - & - & - & + & - & + & $?$ & - & - & $\begin{array}{l}\text { Anatomically verified records in } 2009 \text { in Rivne } \\
\text { and Khmelnytsky regions (GARBAR \& CHER- } \\
\text { NYSHOVA 2011). An earlier mention of this spe- } \\
\text { cies from the Transcarpathian region (POLEVINA } \\
\text { 1959) requires confirmation. }\end{array}$ \\
\hline $\begin{array}{l}\text { Oxychilus } \\
\text { translucidus } \\
\text { (Mortillet, 1854) }\end{array}$ & + & - & + & + & - & - & + & - & - & $\begin{array}{l}\text { First recorded in 2009-2011 in Khmelnytsky } \\
\text { as Oxychilus cf. diaphanellus (BALASHOV et al. } \\
\text { 2013). }\end{array}$ \\
\hline $\begin{array}{l}\text { Deroceras } \\
\text { caucasicum } \\
\text { (Simroth, 1901) }\end{array}$ & + & - & - & - & + & - & + & - & - & $\begin{array}{l}\text { First recorded in } 2014 \text { in Lviv (GURAL-SVERLO- } \\
\text { VA \& SAVCHUK 2019). }\end{array}$ \\
\hline $\begin{array}{l}\text { Xeropicta derbenti- } \\
\text { na (Krynicki, 1836) }\end{array}$ & - & - & - & - & $?$ & - & + & - & - & $\begin{array}{l}\text { First recorded in } 2014 \text { in the Transcarpathian re- } \\
\text { gion (GURAL-SVERLOVA \& GURAL 2017a). }\end{array}$ \\
\hline $\begin{array}{l}\text { Tandonia kusceri } \\
\text { (Wagner, 1931) }\end{array}$ & - & - & - & $?$ & - & - & + & - & - & $\begin{array}{l}\text { First recorded in } 2018 \text { in the Transcarpathian re- } \\
\text { gion (GURAL-SVERLOVA et al. 2019). }\end{array}$ \\
\hline $\begin{array}{l}\text { Monacha fruticola } \\
\text { (Krynicki, 1833) }\end{array}$ & + & - & - & - & + & - & - & - & - & $\begin{array}{l}\text { So far, two colonies are known in Lviv (recorded } \\
\text { in 2019) and near it (2018) (GURAL-SvERLOVA \& } \\
\text { GURAL 2020). }\end{array}$ \\
\hline $\begin{array}{l}\text { Cornu aspersum } \\
\text { (O. F. Müller, 1774) }\end{array}$ & + & - & - & - & + & - & $*$ & - & - & $\begin{array}{l}\text { *In } 2014 \text {, only the fact of an accidental delive- } \\
\text { ry of two individuals from Italy to Vynohradiv } \\
\text { (Transcarpathian region) was recorded (GURAL- } \\
\text {-SVERLOVA \& GLEBA 2016). In 2021, snails were } \\
\text { first found in urbanized habitats (Lviv region). }\end{array}$ \\
\hline $\begin{array}{l}\text { Monacha claustra- } \\
\text { lis (Rossmässler, } \\
1834 \text { ) }\end{array}$ & + & - & - & - & - & - & - & - & - & $\begin{array}{l}\text { First recorded in } 2021 \text { in Lviv (unpublished } \\
\text { data). }\end{array}$ \\
\hline Number of species & 16 & 6 & 9 & 10 & 12 & 7 & 13 & 4 & 5 & \\
\hline
\end{tabular}

